\title{
A New Insight into Symbolic Figures and Special Badges in the Sassanian Rock Reliefs
}

\author{
Houshang Rostami ${ }^{1,}$, Seyyed rasool Mousavi Haji ${ }^{2}$, Zoheir Vasegh Abbasi ${ }^{2}$ \\ ${ }^{1}$ Faculty of Literature and Humanities, Archeology in University Sistan \& Baluchistan, Zahedan, Iran \\ ${ }^{2}$ Faculty of Arts and Architecture, Archaeology in University Mazandaran, Babolsar, Iran
}

Email address:

rostami.houshang@yahoo.com (H. Rostami)

\section{To cite this article:}

Houshang Rostami, Seyyed rasool Mousavi Haji, Zoheir Vasegh Abbasi. A New Insight into Symbolic Figures and Special Badges in the Sassanian Rock Reliefs. International Journal of Archaeology. Vol. 3, No. 6, 2015, pp. 48-62. doi: 10.11648/j.ija.20150306.11

\begin{abstract}
Study of the symbolic figures and badges in the Sassanian rock reliefs is a necessity which has not been independently dealt with in detail till the present time. In the present research it is attempted to study this important issue with the aid of archaeological and historical evidence. In order to achieve this objective, symbolic figures and mysterious badges existing in the Sassanian rock reliefs located in the modern Iranian geographic boundaries were identified and precisely investigated. The current study was most importantly aimed at attempting to perform semiotic investigation for the entire symbolic figures and badges and also to reveal the actual identity and real concept of each of them individually. Results gained of the present research, w4hich is considered as a fundamental research in terms of its objective and is a historical research type regarding its nature and methodology, obviously indicate that the dominant symbolic figures and badges existing in the Sassanian rock reliefs have religious origins; these figures, although represented in numerous forms, each one is considered as a particular symbol in Zoroastrianism. A number of these badges such as the crowns of the Sassanian kings, in various forms, each one represents one of the divinities. Also, the symbolic figures and non-religious badges mainly represent themes such as victory, enemies' captivity, respect, power symbols and imperial glory.
\end{abstract}

Keywords: Sassanian, Rock Relief, Archaeological Studies, Symbolic Figures, Special Badges

\section{Introduction}

The Sassanian rock reliefs have been traditionally well-known and are considered among the valuable great resources and references of the Sassanian periods. Whenever researchers encounter with a new matter of the Sassanian history, or succeed in reading an inscription, or can understand and discover a new cultural works, they always refer to the aforesaid resources and references. These badges serve as the main criteria with which the evidence gained of the Sassanian period can be assessed and hence, significant results and discoveries can be achieved (Lukonin, 1993, 28).

During the Sassanian period, also, like the Achaemenian era, rock reliefs at the first glance seem to celebrate the royal glory and provide the eternal reputation and greatness of the royal dynasty assisted by the symbols and magic instruments. Mentioning the celestial glory and dignity and benediction of the Almightily God to seek grace and provision of the kings' victory over the enemies and aliens, and especially, the Romans, are among the main themes of the discussed relics
(Sarre, 2009, 747). These valuable relics are representatives of a large portion of the Sassanian art, culture, and political and religious approach since each of them has been created to express and convey a real event and concept.

The Sassanian rock reliefs have been already discovered in some regions such as Salmas in the western Azerbaijan province, Taq-e Bostan in Kermanshah, Barm-I Delak, Tang-IQandil, Sarmashhad, Firouzabad, Darabgerd, Gouyom, Naqsh-I Bahram, Naqsh-I Rajab, Naqsh-I Rostam, and Tang-IChougan in Fars province and have been introduced by the explorers and researchers in different ways.

In the rock reliefs remained of this period, there are special mysterious and abstract symbolic figures and badges that each one represents a specific and concept. Diversity and multiplicity of these symbolic figures and special and particular badges is to the extent that it is difficult to keep them in the mind all together and to find out their importance by remembering and recalling them in the mind. On the other hand, some of these symbolic figures and special badges have not been yet undergone semiotic investigations and their 
concept and meaning is still obscure and unclear.

The current study, while performing the semiotic studies of the symbolic figures and mysterious badges existing in the Sassanian rock reliefs, which are located in the modern Iranian geographic boundaries, attempts to conduct a semiotic study on each of them individually and shed light on their actual identity and real concept to the extent that the results of studies allow.

\section{Symbolic Figures in the Sassanian Rock Reliefs}

\subsection{Pitched Battle}

The first time thatthe scene of pitched battle was depicted was during the Sassanian period and this scene relates to the victory of Ardeshir, the Unifier, in Firouzabad (Fig. 1). In this scene, Ardeshir I seeks to demonstrate and prove his legitimacy; a fight to exhibit the merit and competency of a young dynasty with great motivations, with a weakening dynasty, that does not have the competence to rule. This figure is the memorial of a decisive war and victory of the founder of the Sassanian dynasty, Ardeshir, the Unifier, over the last Parthian king. In this rock relief, three scenes are displayed on a flat rectangular surface as follows:

First Scene: The pitched battle of Ardeshir with Ardovan V

Second Scene: Combat of Shapur with Darbandan, Ardovan's minister

Third Scene: battle of Ardeshir's guard and servant with his counterpart

Obviously, such a figure is not derived of a real historical even; instead, it is the result of a series of decisive wars, from which the Sassanian dynasty has been formed. The hatred and prejudice that Ardeshir had towards Ardovan V were to the extent that in Naqsh-iRostam rock relief, he has been displayed equal to demon in terms of his position and Ardeshir has crushed him under his horseshoes (Mohebbi, 14, 2011, 15).

Symbolism in these figures is the pitched battle with the enemy that perhaps, it has not been the case. In war scenes, horse riders and horses have been depicted in quick gallopade and far from reality. Situation of a horse rider fallen from the saddle does not correspond with reality. From the modern perspective, the sensation and excitement that the artist wished to attach to the scene with the quick movement of the deadly raid and defeat the warriors must have led into an exciting scene, but this is not the case. All the things are stable, fixed and frozen. The Sassanian king in this scene should be the only conqueror. He is like this in all the art works, whether he is a warrior or a hunter (Rezaeinia, 2007, 96).

The Pitched battle scene is among the important and symbolic Sassanian motifs. In this motif, as the other similar themes existing on other artworks of this period such as stuccoes, seals, and silver vessels the central focus is on the king; the main aim has been to display the king's warfare and showing the king or the new ruler's merit and superiority over enemies. Pitched battle in the ancient Iran has been one of the important principles of wars; in these battles, the champions of the two armies fight against each other before initiating the war. In Ferdousi's Shahnameh (a collection of the ancient Iranian mythological poetries) also, this has been frequently mentioned; and eventually, this would be ended in the victory and dominance of the superior and rightful power.

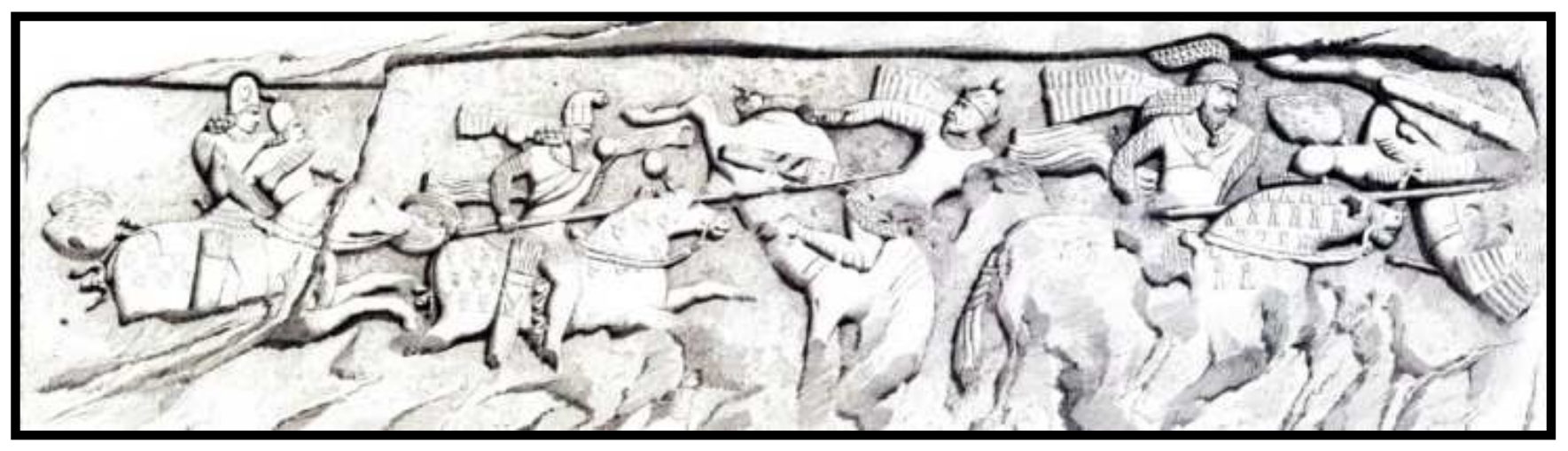

Fig. 1. Firouzabad, Ardeshir I, Pitched Battle Scene (Flandin and Cost, 1851-1854: p.43).

\subsection{Figures Related to the Symbol of Captivity}

The symbol of captivity in the Sassanian period is an indication of a king's greatness and power; Sassanian kings by imprisoning the invading enemy show off their superiority and power to the spectator.

Three victories of Shapour over Guardian III, the Arab Fillip and Valerian, the Roman emperors, have been depicted in one of the rock reliefs of Bishabour left bank. In the central figure, the great king is riding on a horse, and is trampling the body of the Guardian III which is fallen on the ground, and
Valerian, the emperor, is appearing behind the victorious king who has taken his hand. This movement is meaningful and corresponds to the historical description of the Roman king's captivity.

If this is the case, an engraved gem which is preserved in the Medal Forum of Paris Library verifies this issue. According to the Old Iranian tradition, captivity of the emperor has been the outcome of a battle between the two rivals. Valerian raises his sword towards Shapour and Shapour does not even take his sword out of the scabbard and he just contents himself with 
grasping the captive's hand. Grasping the rival's hand has been repeated four times on various rock reliefs (Ghirshman, 1971, 152). Valerian who has acquiescedto captivity, with shame and humiliation, has given his hand to the king; this scene represents the concept of captivity, which an indication of the dominance and victory over an enemy (Mohebbi, 2001, 17 and Soudavar, 2004, 16-17).

The symbol of captivity can be seen in another figure of Shapur I in Naqsh-I Rostam and Ardeshid I in Darabgerd, with the difference that in Darabgerd, Ardeshir, in addition to grasping the enemy's wrist indicating his captivity, the captive person has also raised his hand signing his submission. In another figure related to Bahram II in Bishabur, which is the forth rock reliefs of the right seashore, on the right side of the scene, there seems a number of Persian people, ten induviduals, who are taking two captives to the king's presence (Mousavi Haji, 1995, 175 and Ghirshman, 2000, 120-123) (Figs. 2 and 11).

The tradition of turning captives around cities and employing their capabilities in developmental and economic and even cultural and artistic activities during the history is abundant. Shapur I employed the Roman captives and fulfilled many great tasks. Displaying the ethnic identity of captives has been considered by the sculptors. Also, in victory rock reliefs of Shapur I, the Romans are wearing Roman military clothes and this has been consciously and insistently emphasized (Mohebbi, 2001, 17).

Symbol of captivity during the Sassanian period, has a remarkable representation and it can be mostly observed in figures which contain and harbinger an important historical event or incident. It is noteworthy that showing the symbol of captivity in terms of the importance type of the relevant event has been depicted on the rock reliefs; for example, in the victory rock relief of Shapur I, the Sassanian king with respect to the significance of his historical victory over the Roman emperor and his captivity, has order to depict the scene in such a way that the king, himself, is riding on a horse, in a state representing his grandeur and superiority, grasping Valerian's wrist symbolizing his captivity. However, in another rock relief related to Bahram II, that in terms of importance one can say that it has a lower position compared to the figure of Shapur I; and in this scene, the captives with handcuffs are accompanied by the king's army commanders.

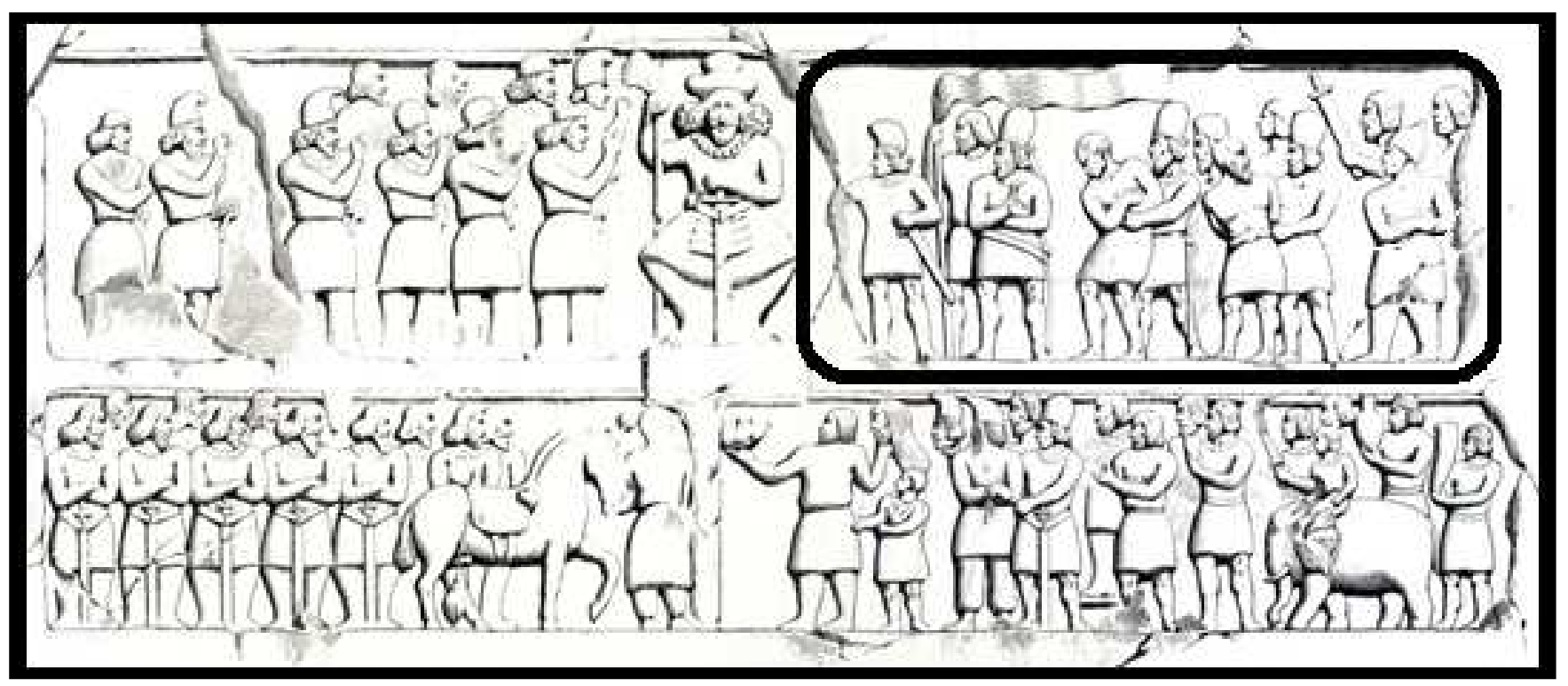

Fig. 2. Bishabur, Symbol of captivity in a scene related to the victory of Bahram II (Flandin and Cost, 1851-1854: p.50).

\subsection{Figures Related to the Symbol of Respect}

Symbol of respect has been repeatedly exhibited in rock reliefs by the courtiers in front of the kings or AhûraMazdâ. Signs and symbols of respect are demonstrated in various ways such as raising the left hand, hiding hands in sleeves in the presence of the king (which has been a respect tradition in the Sassanian court), putting sword in front of oneself and putting both hands on it, bending elbows, putting the forefinger against the mouth and covering the hand by the sleeve. A number of the respect symbols in different scenes are as follows:

Inthediadem granting ceremony of Ardeshir I in Naqsh-I Rajab, Ardeshir, while turning to the right side is receiving the diadem from the right hand of AhûraMazdâ and he has raised his left hand indicating his respect. Here, Shapur has also raised his right hand to show respect and has put his left hand on the sword handle. In this rock relief, according to the court tradition, the left hand is hidden under the sleeve (Hinz, 2006, 171 and Christensen, 2003, 110) (Fig. 2 and 3).

Two adolescents are standing in front of Ardeshir and AhûraMazdâ, that one of them is holding a royal wand and the other one has raised his hand to show respect (Malekzadebayani, 1972, 31). Raising hand to show respect in Mesopotamia has been also an old tradition which can be seen in the Achaemenian rock reliefs (Black and Green, 2004, 51).

In another rock relief related to Shapur I in Naghsh-I Rostam, one of Valerian's hands has been hidden under his sleeve and this state is according to the Iranian court to represent respect and servitude (Ghirshman, 1971, 160 and 
also Hinz, 2006, 242). Face of an Iranian person, who had raised his head and hand to show respect is evident at the back of the king's horse (Christensen, 2003, 247). In the coronation ceremony rock relief of Ardeshir I in Firuzabad, also, the king receives the diadem with his right hand and has raised his left hand with the forefinger bent forward to show his respect according to the tradition of the Sassanian times. In the right half of the scene, three bearded men, with identical garments are standing. These three men have raised their right hands indicating respect and have put their left hands on their sword handle (a symbol of respect) (Hinz, 2006, 170).

The rock relief of Bahram I in Bishabur, which is the fourth rock relief of the right bank: in this figure, the third and the ninth persons have crossed their arms on their chests to show their respects and their hands have become hidden (Ghirshman, 2000, 120).

Sassanian Rock reliefs are narrative of a historical event or incident that kings have ordered to construct them for preserving and remembering these events for the future generations; in these narratives which have been depicted as special assemblies, the kings have been always accompanied by their courtiers and relatives. The artists who have depicted these figures have always considered this point when creating their work; in addition to highlighting the position of kings and AhûraMazdâ, these scenes display the traditions performed in the presence of the kings in the court to his honor and respect.

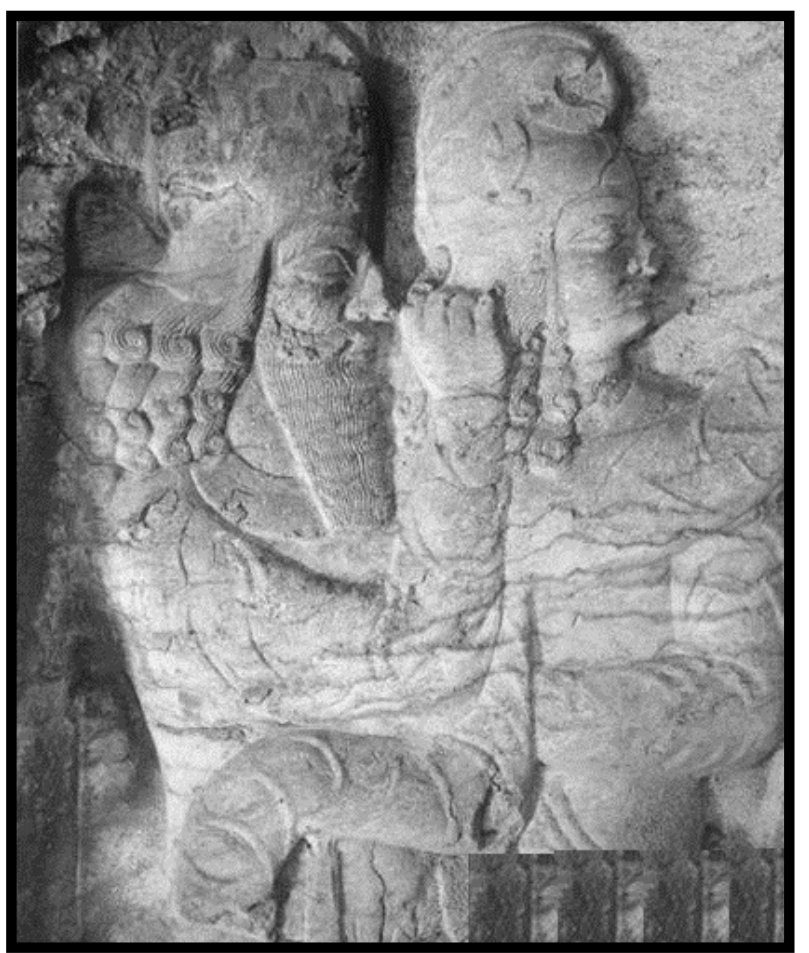

Fig. 3. Naqsh-I Rajab, Reception of Crown by Ardeshir I from AhûraMazdâ, Bending the forefinger and covering the hand by sleeve to show respect (http://oi.uchicago.edu/gallery/sasanian-rock-reliefs-naqsh-i-rustam-and-na qsh-i-rajab).

\subsection{AhûraMazdâ}

The oldest Sassanian rock relief indicates the ring of kingdom or kingship position being received from the great god, AhûraMazdâ, by the first king in the Sassanina dynasty, i.e. Ardeshir the Unifier.

Sassanian kings believed that their powers were originated from AhûraMazdâ. Consequently, in rock reliefs and behind coins, Sassanian kings introduced their nature to be related toAhûraMazdâ. However, Sassanian kings believed their powers to have a celestial origin and they have indicated this issue in their coronation ceremonies and at the back of their coins. Presence of AhûraMazdâ in the coronation ritual is for sacredness of the power and granting the same to the king. In the coronation ceremony, AhûraMazdâ wears garments like kings, rides on a horse just like them, and his appearance is a combination of political power and cleric spirituality; by submitting the monarchy ring to the king, he affirms the celestial origin of the king's power, and indicates that he would guarantee the maintenance of the submitted power (Asil, 1999, 197). The human image or incarnation of AhûraMazdâin rock reliefs whose subject is coronation or diadem granting includes:

Ardeshir I in Firuzabad (Mousavi Haji, 1995, 76), Naqsh-I Rajab and Naqsh-I Rostam (Hints, 2006, 1717-176 and Christensen, 2003, 166) (Fig.3).

Shapur I in Naqsh-I Rajab (Mousavi Haji, 1995, 76) and Bishabur (ibid, 221).

Bahram I in Bishabur (Ghirshman, 2000, 13-14).

Ardeshir II, in Taq-I Bostan (Ghirshman, 1971, 190-191).

Piruz I, in Taq-I Bostan (Mousavi Haji, 2008, 85).

AhûraMazdâ or Urmazd, which means "wise master" is a name given by the Zoroastrians to the God. As it is clear from his name, his characteristic is wisdom, someone who is never deceived or deceives. This master is considered as merciful and summonsbonum (omnibenevolent). He, who is the parent of the creation, has built the path of the sun and moon and stars. He has existed and will exist. In other words, he is eternal, but at the time being, he is not the omnipotent since his ability is restricted thanks to his major enemy, i.e. the Demon. However, a time will arrive when evil would be overcome ad AhûraMazdâ would rule with omnipotence (Hinnells, 1994, 69-70). About Ardeshir I rock relief in Naqsh-I Rostam, it should be noted that in this image, abundant ritual beliefs are hidden.

Victory of Hermazd over the Demon would be completed at the end of the historical age of the universe, when everyone is waiting for. Victory of Ardeshir over the Parthian has been occasionally for the final goodness and virtue over evil and cruelty, which has become eternal by this rock relief (Herzfeld, 2002, 317-318).

During the Sassanian period, for the first time, an official religion dominated the country, and policy of the Sassanian kings was formed based on a mixture of the religion and government. According to this approach, the Sassanian king using an instrument made of religion and religious beliefs sought to legitimize their government; therefore, for the first time, during this era, we observe incarnation of AhûraMazdâ as a human. In the rock reliefs, AhûraMazdâ has been physically and also in terms of his appearance depicted 
identical to a king, and he is dedicating the kingship ring to the Sassanian king; and in other words, the king is the representative of AhûraMazdâ on the earth and the material world to fight against the demon and to establish the rule of light and brightness.

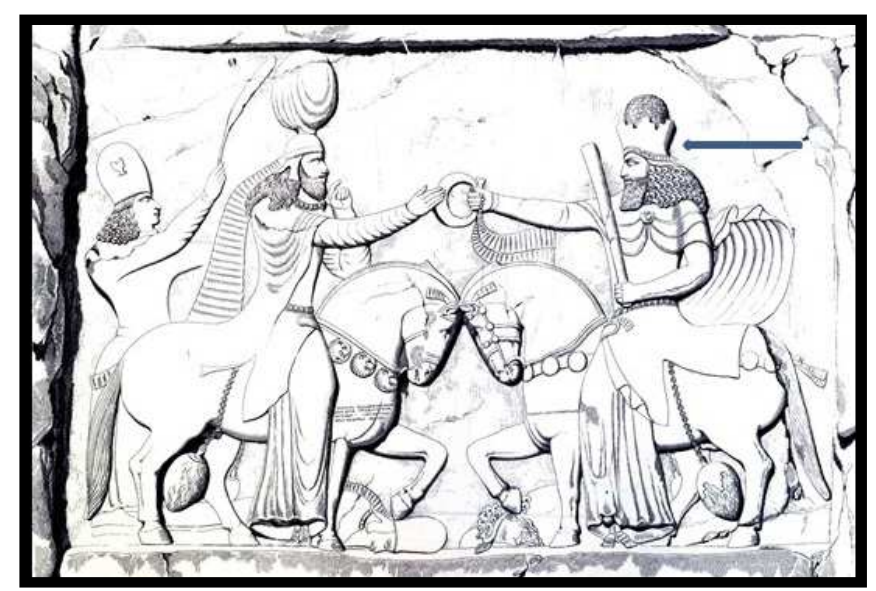

Fig. 4. Naqsh-I Rostam, Receiving of the crown from AhûraMazdâ by Ardeshir I (Flandin and Cost, 1851-1854: p.182).

\subsection{Mitra}

Mehr (Mitra) is the name of a divinity in Mazdisni religion. In Avesta and the ancient Persian, this name has been stated as "Misr" and in Sanskrit, it has been stated as "Mitar" or "Misar" and in Persian it is called as "Mehr". The meaning of this name is the treaty of friendship, affection, and also the divinity of brightness and light. In Avesta, Mehr is one of the divinities, and a Yasht of the Book of Yashts called MehrYasht has been written to praise her (Afifi, 1995, 624).

Mitra has been one of the Indo-Iranian divinities before Zoroaster; although Zoroaster abolished the worship of Mitra, after him, in Mazdisna religion, she was transformed into one of the eminent angles or divinities (Shams, 2000, 204 and Ulansey, 2001, 18-19 and Guillemin, 1996, 219).

The divinity of Mehr (Mitra) appeared since the Sassanian period in the rock reliefs of Ardeshir I in Taq-I Bostan and this should be considered that the Greeks worship of gods and goddesses during the two-hundred-year ruling of the Macedonians and Seleucids in Iran could have been influential in this issue (Pourhaghani, 1998, 37). The symbolic presence of Mehr in the coronation scene is also an indication of believing in a celestial origin for the kings' power. In this rock relief, receiving the crown by Ardeshir II in Taq-I Bostan, Mehr is standing on lilies and is holding a bunch of Barsem. It can be said that, presence of Mehr is a symbol of this divinity's support from the treaty between AhûraMazdâ and the king; this symbol of light and brightness protects the king against darkness and demon, and grants him blessing and sanctity (Asil. 1999, 199 and also Herzfeld, 2002, 333) (Fig. 5). In the Avestian and Pahlavi texts, there are various references to Mehr. Some of these references are mentioned below.

In Bunadahis, it has been mentioned about Mehr that: Mehr is in charge of the judging about the honest of all the people in the world (Bahar, 2001, 133).
In Khorda Avesta in Gahan (Five Times), there are some references to the divinity of Mehr and and she has been praised (Khorda Avesta, 2003, 68).

In Minuy-e Kherad, it has been mentioned about Mehr's duty that Mehr is a divinity whose main responsibility is to supervise treaties. Mehr, Sorush, and Rashan are viewed as three judges who appraise people's deeds after their death (Minuy-e Kherad, 1985, 98). In Vandidad, the fourth chapter, it has been stated, "If someone in this physical world consciously does that big work (remains without wife and family, children and wealth), it would be as if he has told a lie to Rashno (the angle of honesty) and he has broken the promise to Mehr (the angle of promise) and has approached to the bright golden savory water (because in Zoroastrianism, water is considered to be sacred and if a sinner approaches to it, his/her sins would become very heavy) (Vandadid, 1982, 37). In the $19^{\text {th }}$ chapter: We praise Mehr, who has extensive fields and good weapons and the brightest weapon and the most victorious weapon (ibid, 145).

In Yasnâ, Hât 65, 66, and 68, Mehr has been mentioned in different topics such as getting help from Mehr or saying pray to him (Pourdavoud, 1978, 90-96-104).

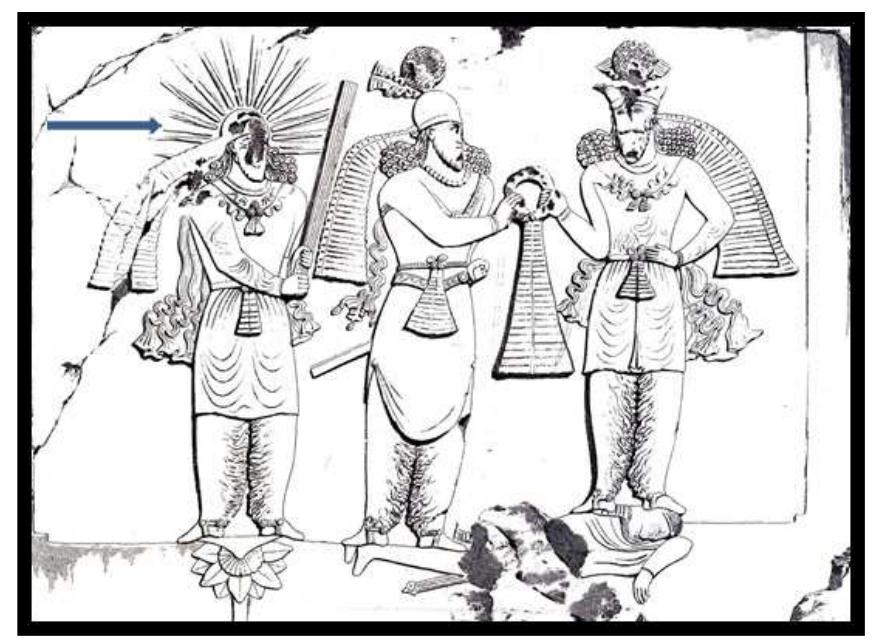

Fig. 5. Taq-I Bostan, Ardeshir II receiving crown from AhûraMazdâ in the presence of Mitra (Flandin and Cost, 1851-1854: p.14).

Mitra is one of the Proto-Zoroastrian divinities whose worship was abolished with the advent of Zoroaster. During the ruling time of the Achaemenid Darius I, despite the religious tolerance and negligance, no trace of other divinities can be observed and it is only AhûraMazdâ who has been mentioned and praised by Darius. In other words, AhûraMazdâ undertook the duties of the all other divinities on his own. Over time, the period of the Achaemenian Ardeshir II witnessed the reappearance of Mitra in his inscriptions and he paved the way for return of the other pre-Zoroaster divinities. But during the Sassanian period, major changes occurred in the Zoroastrianism aligned towards the political goals and interests of the Zoroastrian priests and kings. During this period, the divinities emerging in human figure were appeared to legitimize the ruling of the Sassanian kings; and in the instructions of this Zoroastrian 
period, oppositions and fights of the pre-Zoroaster divinities have been forgotten and replaced with the string attendance of these divinities as AhûraMazdâ's (the great God) assistants in religious textures and other artistic work including the rock reliefs. Presence of Mitra in the rock relief of Ardeshir II along with AhûraMazdâ is also among the king's attempts to legitimize his ruling. This rock relief is significant due to the fact that in addition to AhûraMazdâ from whom he is receiving the kingdom ring, Ardeshir II has exploited the presence of Mitra to duplicate his legitimization; and attendance of Mitra in this assembly means supporting a treaty that the Sassanina king is contracting with AhûraMazdâ, and Mitra as well as supporting the king, assists him in achieving these goals.

\subsection{Herakles}

Presence of Herakles as a Greek god in the coronation assembly of Ardeshir I, who institutionalized the Zoroastrianism for the first time and called himself a real religious, is very remarkable. In the following, the above-mentioned rock relief and presence of this Greek god are described.

Naqsh-I Rajab, Receiving of the crown from AhûraMazdâ by Ardeshir I: figure of two children between Ardeshir and AhûraMazdâ is noticeable, while the person on the right side of the scene is naked. This figure in the Iranian sculpture art is inconsistent with the norms and traditions and hence, certainly, one can assume that one of the Greek divinities may have been involved. However, he is holding a bunch of Barsam in his right hand and apparently, he has taken an Iranian character. Therefore, I suppose that he might have been Herakles who has been equal to the divinity of the ancient Iran during the old ages, "Bhram". The resistance breaker divinity and the god of war who has been called "Varharan" during the Sassanian period and later he was named as Bahram. If I am right in interpretation of the damaged cliff, this divinity has leaned his left hand on a wand (Hinz, 2006, 172) (Fig. 6).

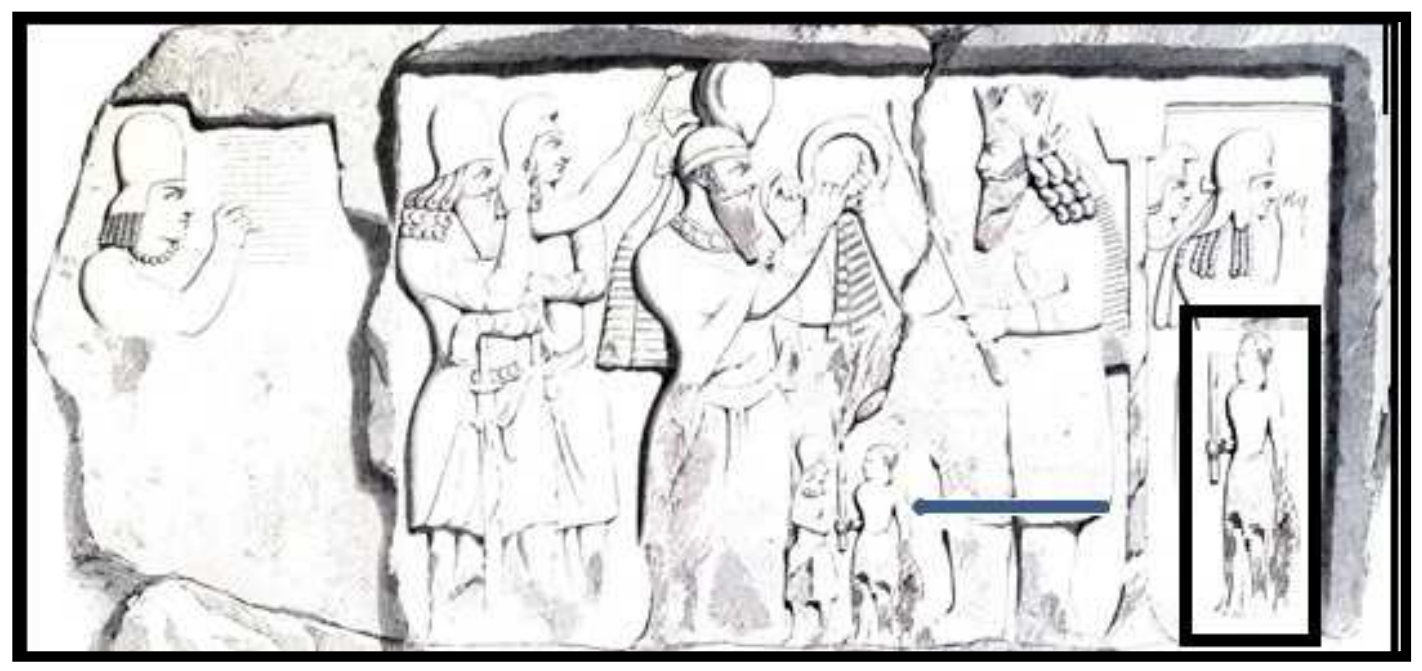

Fig. 6. Naqsh-I Rajab, Coronation of Ardeshir I, along with Herakles's figure (Flandin and Cost, 1851-1854: p.44).

Hartsfield also argues that this figure represents Herakles. In Naqsh-I Rajab, two children are standing between the king and the god. The child on the left side who is wearing the same clothes as adults is probably Ardeshir's grandson, who later ascended the throne under the name of Hormozd I. He is paying his respect to the entirely naked child on the right. Image of this naked child is among the unique characteristics of the Sassanian art. We can say with confidence that this is the figure of a Greek divinity (Herzfeld, 2002, 317).

Herakles is one of the most famous champions of the Greek mythology and son of Zeus. Herakles is the symbol of ability, powerfulness, and championship. He is not only a champion, but also he had been worshiped as a divinity (Smith, 2005, 371-366).

Herakles, who has been called Hercules by the Romans, is the most famous and national hero of the classic Greek stories (Grimal, 1968, 375 and Dickson Kennedy, 2006, 386-387). He was the son of "Amphitryon" and "Alcmene" but his real father was Zeus. According to some literature, Herakles after killing his children of his first marriage, based on the call of Pythian of Delphi temple, in order to compensate for his sins, he had to perform twelve of his steps under the command of Orstious, king of Argus. In the Greek art and later in the Roman art, figure of Herakles is depicted as a stout man with shaggy beard who is usually naked; he is either standing or leaning on his wand, or is laying or performing one of the mythic steps. Many figures of Herakles have been found in some sites such as Susa, Seleucia, Assyria, Dura-EuroposHetra, Nesa, MasjedSoleyman and some other places. Also, the Hellenistic image of Herakleshas inspired many artists in the Parthian territory who have adorned these Hellenistic images with oriental features. Some traces of these kinds of work can be seen in Tang-I Sarvak, Susa, Shimbar, Masjedsoleyman and some other sites (Ghaderi, 2006, 83). Figure of Herqel or Herakles has been found in MehrdadKalinkus rock relief or probably AntichosKomajen located in NamroudDagh foothill, in which he is shaking hand with Herqel's god (Colledge, 2001, 135). 
Presence of Herakles in one of the most important and first Sassanian rock reliefs (Ardeshir's receiving the crown from AhûraMazdâ) is of interest due to the following reasons: we observe the attendance of a Greek divinity inconsistent with the Iranian artistic tradition for the first time; and moreover, in a ceremony which is completely a religious occasion and all the Zoroastrian ritual elements are present in it, one of the Greek divinities also attends.

That Hints calls the object being hold by Herakles as Barsam and he attributes an Iranian character for him is not much acceptable since even in terms of clothing, the Greek god is not wearing even a piece of cloth so that at least, one can comment on his identity according to the type of his garments; and the discussed object, if it can be called Barsam, this question arises: why a Barsam which should be held by the Mazdisna divinities and clergymen for praying is being held by Herakles? And, when AhûraMazdâ is holding Barsam in his hand why Herakles is holding a Barsam in his hand too? Does it mean that at that time, a position as high as the Iranian divinities had been allocated to Herakles? The answer to this question is "no", as Ardeshir's period is considered as the outset of the time when Zoroastrianism was recognized as the official religion in the Sassanian territory and all the principles and obligations of this religion had been observed as much as possible and it is unlikely that a Greek god could have had a status equal to the other Iranian divinities. Perhaps, according to the cultural effects and relationships and similarities of him to Bahram, presence of Herakles could be explained; however, such a strong presence cannot be attributed to him.

\section{Special Badges in the Sassanian Rock Reliefs}

\subsection{Hearth}

Hearth is one of special and important badges of Zoroastrianism; during the Sassanian period, for the first time, this religion was entirely recognized as the official religion around the country. But in rock reliefs of this period, only in the coronation ceremony of Ardeshir I in Firuzabad, hearth has been identified (Fig. 7).

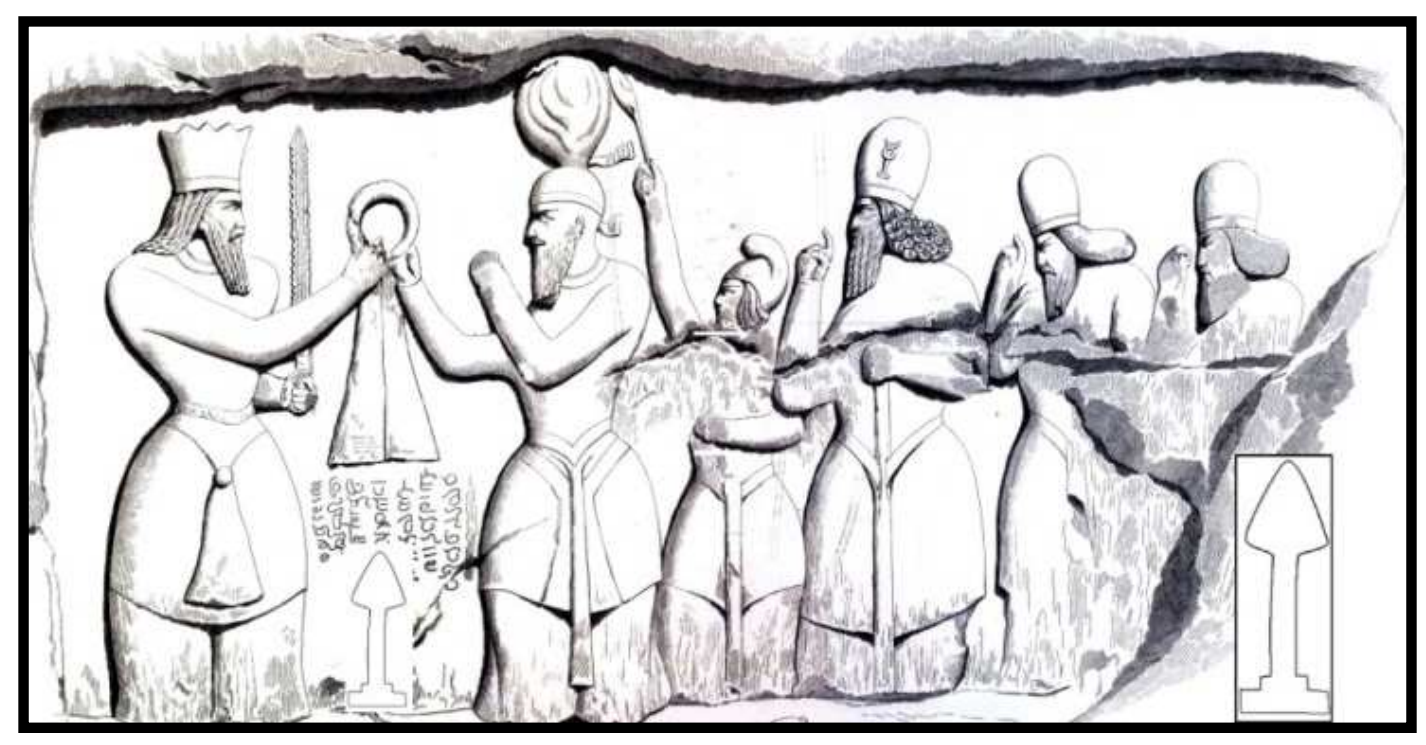

Fig. 7. Figure of a Hearth in Ardeshir'sreceiving of the crown from AhûraMazdâ (Flandin and Cost, 1851-1854: p.51).

In the rock reliefs of the Achaemenian royal graves in Naqsh-I Rostam, some hearths are seen which are burning at the top of the holly fire (Christensen, 2003, 183). Gradually, in the Zoroastrian religion, this rule was established that sun should not shine on the fire; therefore, a new style in building the fire templesprevailed. An absolutely dark room used to be built in the middle of the room where the hearth was place. At the back of the official coin of Pars who was a Seleucid tributary, image of this hearth is observed. On the mentioned coins, three hearths which are typically placed in the middle of the fire temple are depicted above the fire temple. On the left side, a person is worshiping and on the right side, a flag is seen. Details of the hearth are better evident in the coins of Ardeshir I (ibid, 184).

The Aryans believed that fire was the basis and essence of life and existence and they thought that there had been a relationship between fire and plants. Also, they assumed that there had been a close relationship between fire and ancestors' souls (Afifi, 1995, 406).

One of Farrah's manifestations is fire. The Mazdean tradition viewed Farrah as the essence of fire. Appearance of fire in the Sassanian art domain as a hearth figure is a formal badge in the Sassanian world. Farrah is a spiritual quality which is rooted in the cultural and living conditions and beliefs of the human during the ancient ages. This concept can be sought in other nations' collection of rituals and mythologies. In Iran, the term Farrah, and especially, Farrah-e Izadi (the divine Farrah) found a profound religious and political meaning. Accordingly, the divine Farrah is a power granted to the king-a Zoroastrian priest who has a semi-divine identity-so that he could exert his authority, material and spiritual dominance on the society. The Zoroastrian Farrah 
reincarnated in his mother in the form of fire and it was penetrated into the child's body from the mother's existence. It is noteworthy that, in order that the ancient human could be associated with religious and mythical concepts and notions, these elements necessarily became subjected to some forms and badges (signs) so that the human's mind could have the capacity to perceive and accept them. Farrah was not an exception in this regard, and it was incarnated as material forms and elements like most of the spiritual concepts (Movaheddi, 2002, 122 and 123).

Ardeshir I simultaneous with establishing the Sassanian dynasty, declared the Zoroastrianism as the state's official religion; and for the first time, he mingled the religion and politics during this period. Ardeshir, as the founder of the Sassanian dynasty, has exhibited himself as a religious person and due to the same reason, in the coronation scene in Firuzabad, he has displayed the religious symbols and badges as much as possible. Among these symbols and badges, figure of a hearth is one of the special and important symbols and badges in Zoroastrianism which has been depicted in this assembly. According to the importance of hearth, as it was previously noted, only in the mentioned rock relief, we see the depiction of a hearth and in other rock reliefs of the Sassanian kings there is no trace of its emergence. The reason for this could be probably sought in the important political and social changes and religious policy shift that occurred during the ruling of the subsequent kings. Among these events, advent of the Manichaeism religion during Shapur period, replacing AhûraMazdâwith the goddess Anahita in Nersi rock relief in Naqsh-I Rostam can be mentioned.

\subsection{Barsam}

Barsam is one of the other special badges in Zoroastrianism.
Barsam can be observed in the following rock reliefs: Receiving of Barsam by Ardeshir I from AhûraMazdân Firuzabad, Coronation of Ardeshir I in Naqsh-I Rajab, Ardeshir I in Naqsh-I Rostam, and coronation of Ardeshir I in Taq-I Bostan.

In the coronation scene of Ardeshir I (Firuzabad), in the left side of diadem receiving assembly we have AhûraMazdâ who is granting the kingship diadem to Ardeshir. AhûraMazdâ is holding something in his left hand which has been often called Deboūs, but it is indeed the holy bunch of Barsen (Barsaman, Barsem) which plays an important role in Zoroastrianism (Hinz, 2006, 170) (Fig. 8).In another rock relief, related to Ardeshir I in Naqsh-I Rostam, the divinity is holding a Barsem in his left hand, which has been among the obligations in the Iranians' religion and its antiquity dates back to the Median times (Herzfeld, 2002, 317-318 and also Hinz, 2006, 176). Also, in Taq-I Bostan, Ardeshir II is standing and two divinities are seen on both his sides, one of them is AhûraMazdâ, who is granting the crown, and the other one is Mitra who is holding the bunch of Barsem in her hand and her head is shining (Ghirshman, 1971, 190-191).

Barsem is considered as a sign of divinity (Curzon, 1983: 152). There has been a tradition among the Iranian and Hindu clergymen that while performing the religious ceremonies, they should hold a bunch of Barsem (plant heirloom); over time, grass and plant heirloom were replaced with branches and twig (Boyce, 1997, 396).

In Yasnâ, Hat 59 (Hat here means chapter) it has been stated that: I praise, Bahram created by AhûraMazdâ, I praise the victorious Soushiant. I praise (ZoutRaspi), this rightly expanded Barsem, with Zavar (and) Kustī(Barsem). I praise my own soul and I praise my Farvahar (Pourdavoud, 1978, 71).

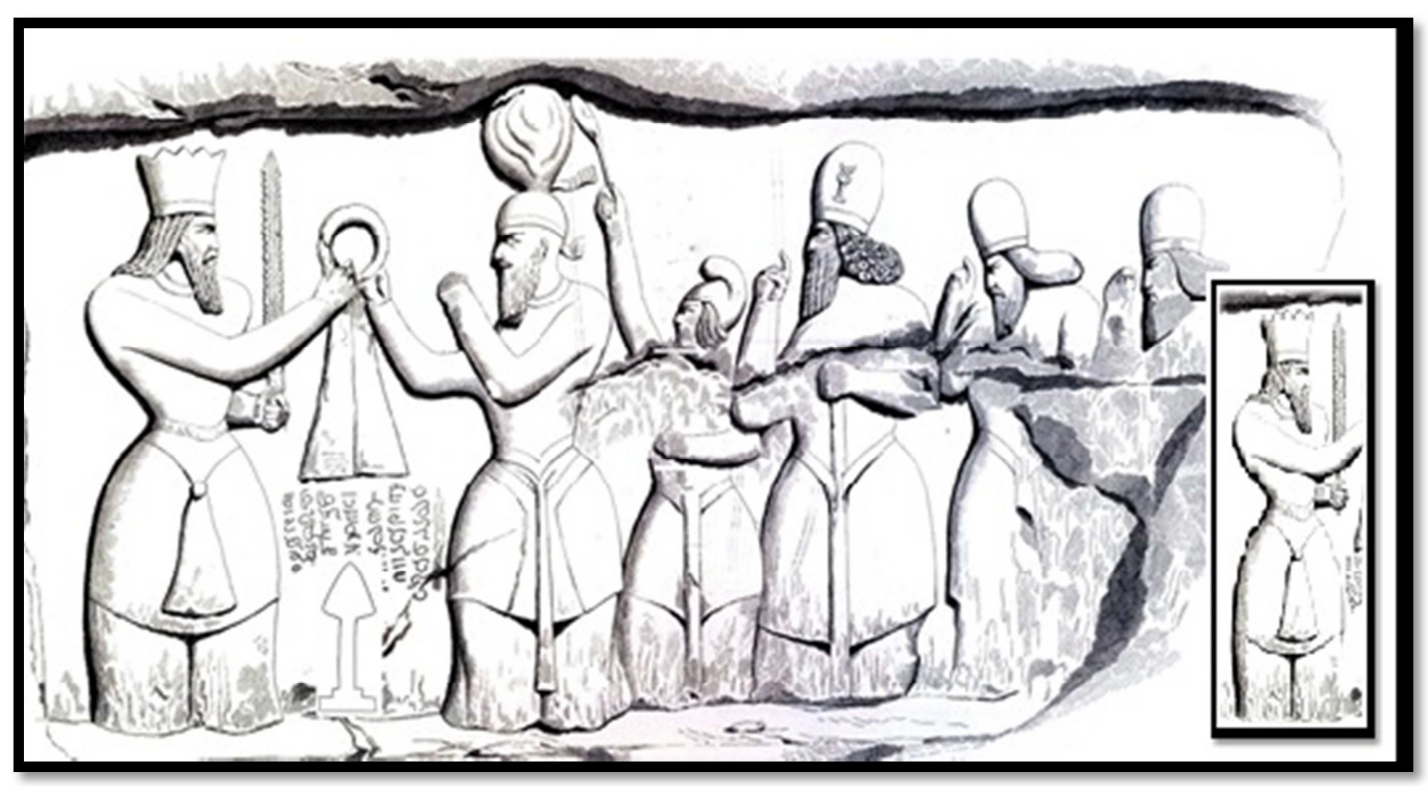

Fig. 8. Firuzabad, Coronation of Ardeshir I, Barsam in AhûraMazdâ's hand (Flandin and Cost, 1851-1854: p.51).

Barsem is a bunch of tied together stems which used to be presented while praying and invocation as $\mathrm{s}$ sign of appreciating the nature in the ancient Iran (Chevalier and Gheerbrant, 2006, 77). In other words, Barsem is made of the 
branches which have been cut from a plant or tree that had been held by Zoroastrian priests during religious ceremonies. In Avesta, this term has been mentioned as Barasaman, and throughout the book the name of Barsem has been used. However, nothing has been mentioned that from which plant or tree Barsem should be prepared. In Shayest and Nashayest (translated as Proper and Improper in English), it has been stated that this should be prepared from a pure tree, every branch of Barsem is called Tak or Ta and in later books, preparation of Barsem has been recommended to be done from pomegranate branches (Afifi, 1995, 457). Holding Barsem means praying and thanking God for benefiting from the plants which are the sources of human and livestock and the means of the nature's ornament. Traditionally, before eating, people used to hold Barsem in their hands and pray and thank God for his blessing (Oshidery, 1999, 162).

Barsem is another one of the religious badges in Zoroastrianism; AhûraMazdâ in the coronation assembly, holds Barsem in his hand while dedicating the diadem to the king; and he prays for the success and victory of the king as his successor on the earth and the material world; and also, he prays for his fighting with the evil force and expanding the state of light and brightness on the earth.

\subsection{Crown}

The Sassanian kings' crown has a special importance for researchers, since a way of identifying the identity of the Sassanian kings among the remained relics of this period is referring to these crowns; in addition, each of these crowns, according to the particular characteristics and shapes they have, represents or symbolizes one of the Mazdisni divinities. In Firuzabad, the coronation scene of Ardeshir I, the king with a crown which is characteristic of him and is consisted of the mentioned combat helmet and forelock (like the sun) is standing in front of AhûraMazdâas high as him (Hinz, 2006, 170). Ardeshir's crown which resembles to a sun is another symbol of Farrah, and sun, as a source of light, is directly related to the perception of the Zoroastrian human of the light origin of Farrah. The visualization manner of the sun in the Sassanian art and civilization has been placing of a sphere on the king's crown or the form of the portrayal of this element varies in artwork (Movahedi, 2002, 124). In the coronation scene of Ardeshir I (Naqsh-I Rajab), AhûraMazdâwith a jagged crown is standing in front of Ardeshir,looking at the left side (Hinz, 2006, 171). In Naqsh-I Rostam and Darabgerd also, Ardeshir's crown has been depicted in the same form and quality. However, in Ardeshir's coins, he has been depicted with a jagged kingship crown. This kingship crown is a sign of AhûraMazdâ(Lukonin, 1393, 71).

Since then, Ardeshir has been observed with a tower-shape modeled from Urmazd's crown (Ghirshman, 1996, 336). Ardeshir attributed himself to the divinities lineage. The new title represents the divine status of Ardeshir; this crown is of a dentate type which was used by AhûraMazdâ (Rezaeinia, 2008, 36). In Nagsh-I Rostam, Shapur's crown is also of the jagged types on top of which there is a big sphere. In Bishabur, the third figure of the left bank, coronation of Bahram I: the king is riding on a horse, opposite the divinities, is wearing a crown on his head, which has several beam-like blades (symbol of Mitra) (Ghirshman, 2000, 13-14). Bahram I has had a peaked crown which may be the reminder of Mehr, or in his successor's crown, Bahram II; first, we see a pair of wings which is a characteristic of the divinity of the kings, Varharan (Bahram) (Ghirshman, 1996, 336). The second figure on the right bank is reminder of Bahram II (Defeat of Arabs): this rock relief displays Bahram II riding on a horse on the right side; his upper body has a front view and the face has a profile view. He is wearing a winged crown on his head symbolizing the god, Vartega (victory) and a kingship headband has been placed on this crown (Ghirshman, 2000, 109). The king is wearing the crown of the divinityBahram who has the same name. The crown is consisted of a pair of Varghane's wings, which is one of the representations of the divinity Bahram (Herzfeld, 2002, 329). Since the period of Bahram II (238-275 A.D), kingship crown has been ornamented with a falcon's wing. In Zoroastrianism, also, falcon has a high importance since it is the seventh form of the divinity Bahram.

In the ancient Iranian tradition, Shahin (falcon) is another name and symbol of Bahram; falcon is the symbol of Farrah (Asil, 1999, 216-217 and also Soudavar, 2004, 23-24). Sometimes, the figure of falcon has been depicted in its upper-body view, or its head or body, and sometimes, its wings have been exclusively shown. The family emblems of many royal families or the Sassanian princes and elites have been consisted of one or two falcon wings (MalekzadehBayani, 1972, 25). Since the kingdom of Bahram II, most kings' crowns have been decorated with the head or upper-body or wings of a falcon (ibid, 26). Placing of wing on human or animal body is a divine sign and symbol of the protective power. Winged images are resulted fromdisplaying the holy birds such as falcon and vulture in Egypt (Horus), and eagle in the Middle East (Hall, 2001, 30). Members of the southern Iranian dynasties during the Parthian period have an eagle figure or a crescent on their hat or combat helmet, while the Parthian kings applied the figure of star or horn or similar figures. Similarly, the Sassanian kings decorated their crowns with star, crescent, sphere, and or bird wings which are nearly representations of the eagle, the sun bird. Moreover, among the common symbols of the Sassanian seals, the most typical and significant of them is the crescent shape (Ackerman, 2008, 997).

Sections of the Sassanina kingship crown have had specific symbolic badges which were associated with Zoroastrian rituals (Lukonin, 1993, 71). In general, symbols of the Sassanian kings' crowns are as follows:

Crown Jag: symbol of AhûraMazdâ

Ray of light: symbol of Mehr or Mitra

Eagle or hawk's head: symbol of Varsaghan or Bahram divinity

Moon crescent: symbol of the moon divinity, frequently, a figure of a star along with the moon, which is occasionally appeared in other combinations; therefore, concept of this badge varies.

Ram's horn: symbol of Varsaghan or Bahram divinity 
Eagle or hawk's wing: symbol of Varsaghan or Bahram divinity.

A crown itself is a symbol of dominance and power of kings. However, what can enhance its importance are its symbolic badges. The Sassanina kings' crowns were not identical. Every king who ascended the throne wore a different crown. The distinction of the kings' crowns was in their jags and jewels. These badges were the divinity-related symbols and they had been used to indicate the close relationship between the kings and the divinities. Shapes of the crowns are easily recognizable; since they have been created by various selections and a combination of signs. These signs are the symbols of the divinities which had been intended to show the close relationship between the god and the king (Pordada, 1979, 290) (Fig. 9).

By investigating the Sassanian kings' crowns, in addition to finding out the historical identity of the given king, religious beliefs and attitudes of the kings during different periods can be perceived as each of the crowns has been made with a set of special badges and according to the king's tendency and appeal to each of the Mazdean divinities.

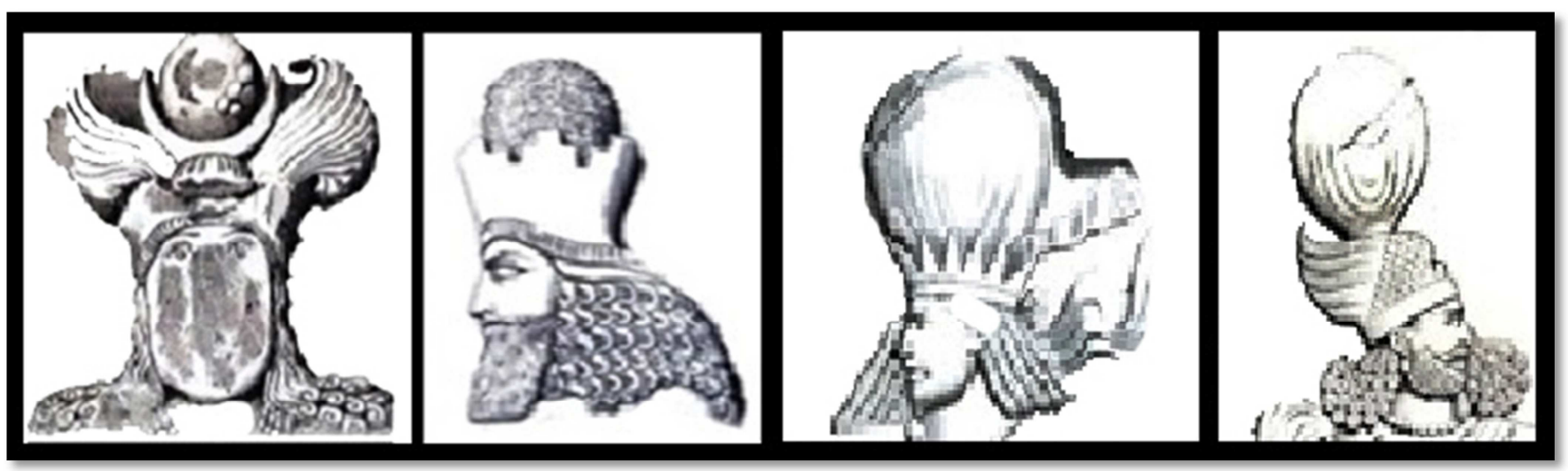

Fig. 9. Several examples of the Sassanian kings' crowns (Flandin and Cost, 1851-1854: p.51, 14, 52, 9).

\subsection{Kingship Ring}

In the Sassanian rock reliefs, divinity of a king's position is usually visualized as a ring which is being dedicated to the king and in one case to Anahita by AhûraMazdâindicating the legitimization of the divine reign. The rock relief of Ardeshir, the Unifier, in Naqsh-I Rajab, is the first and oldest scene in which sanctity and divinity of the king's position have been depicted (Mousavi Haji, 1995, 65).

Coronation is an indication of a divine confirmation which legitimizes the king's rule and grants him power. The Sassanian kings claimed that kingship had been submitted to them by God and they have frequently exhibited this theme in the Sassanina inscriptions. Also, in the real world, they receive their crown from the Zoroastrian priest (Rezaeinia, 2007, 96); or in other words, it can be said that: crown reception ceremony is a symbol of kingship assignment which is confirmed by divinities. In the Iranian iconography, a diadem can be regarded as the representation of kingship Khorneh, divine confirmation or fortune that by submitting it from the god to the king, his power and authority is sanctified (Rezaeinia, 2008, 37).

In Salmas rock relief, the approval sign of the local governor is done by the king. Ardeshir, in this rock relief, according to his status, has some positions and authorities to recognize the local governor's rule and grants him the legitimacy ring. In other words, this ring or diadem should be considered in a rank lower than the ring which is being granted by AhûraMazdâ to Ardeshir.

Ghirshman describes this scene as follows: but Salmas rock relief, which is the scene of the local governor's approval by
Ardeshir and his son, Shapur. In Salmas rock relief, each of the kings has granted a ring indicating the power submission to a person who is on foot (Ghirshman, 2000, 141).

Another type of ring can be called the "victory" ring that in is being granted to the king by the courtiers and the Roman captivesShapur I rock relief in Bishabur. According to the mentioned points, the Sassanian rings can be divided into three types:

The kingship and power ring which is submitted to the king by AhûraMazdâ(Fig. 10).

Power submission ring dedicated by the king to local rulers to assign them as the governor of an imperial region, an example of which can be seen in Salmas rock relief.

The ring of victory which is an indication of the king's victory in the war.

Christensen regarding the ring and Barsem in Ardeshir assembly in Naqsh-I believes that, Urmazd (AhûraMazdâ) is holding the kingship ring in his right hand and the kingship rod in his left hand, and both of them are granting the kingship sign to the king (Christensen, 2000, 13-14).

Another ring which has been called the ring of victory is observed in the rock relief of Shapur in Bishabur which is the first rock relief of the right side bank: the person behind Philip is a Persian person and perhaps a high-rank person who is standing there. His right arm is bent and ended in a cover. The second person has placed his left hand on the sword handle and his right hand is raised up towards the king and is moving the probable ring,which is perhaps a sign of victory,with this hand in the air. It is likely that this person is a prince recognized in the central scene of the previous rock relief (ibid, 
96-100).

A ring resembles the circular symbols in several aspects in terms of eternity, continuity, divinity and life; it is the manifestation of strength, esteem, authority, and power. Ring in British coronation ceremonies is an indication of kingship position (Cooper, 2001, 121). Diadem can be considered as the royal power, authority, succession, and endless continuity (ibid, 163).

A ring along with a whip as the power symbols of "Yameh"had been granted to AhûraMazdâ by one of the first Aryans (Jamshid in Shahnameh) which is associated with sun.
He has been characterized by different names and title such as luminous (Khashaiat) which is itself a characteristic of the sun. Yameh has used the ring and whip three times, so that by consolidation of his power he could expand his power and provide extensive pastures for the growing number of the herds (Ackerman, 2008, 993). Figure of the royal diadem is also observable in most of the Sassanian relics (Farbod and Jaafarpour, 2007, 70). Regarding the ring or diadem this point must be mentioned that the ring or the diadem should be investigated according to the subject and the event which has been occurred in the given rock relief.

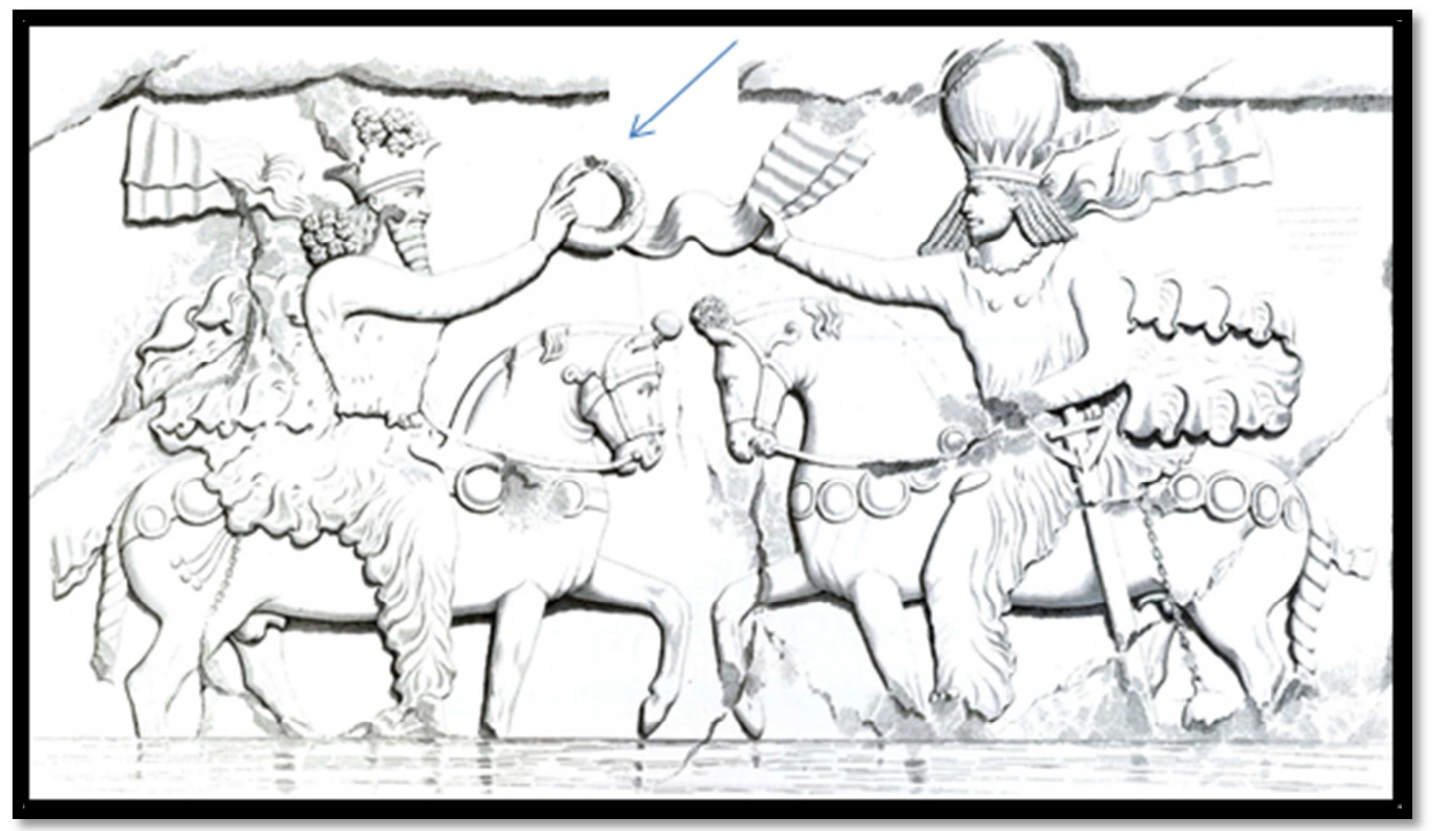

Fig. 10. Bishabur, Coronation of Bahram I; AhûraMazdâ is dedicating the kingship ring to the king (Flandin and Cost, 1851-1854: p.52).

\subsection{Ribbon or Band}

A curling ribbon or band which is one of the important figures in the Sassanian art has a very significant presence in the artworks of this period, including coins, vessels, hand woven things; and this badge has been widely reflected in the rock reliefs. In general, it could be stated that ribbon is manifested in various forms in all the rock reliefs of this period. Bands have been usually attached to kingship rings, kings' crowns, on AhûraMazdâ, Anahita, and Mitra's garments and crowns, on horse heads and tails, the crescent in Taq-I Bostan, in the goddess Nikeh's hand in a wavy manner; and in some cases, ribbons have been fasten to the king's back or lags. In the following, a description of the band or ribbon in some of the Sassanian rock reliefs is presented.

In Darabgerd, in the rock relief related to Ardeshir I, the king is hanging a very precious necklace around his neck; from three parts of his body, twin bands which are indication of Farrah are hanging in a wavy manner (Hinz, 2006, 200). In Taq-I Bostan and the coronation ceremony of Piruz I, in Nahid's left hand a container from which a liquid is flowing and on her right arm a ribbon ring can be observed (Harper, 2006, 143). In addition to the ribbon hanging from the ring held by Anahita and AhûraMazdâ, a ribbon has been also hung of the moon crescent which is located on the upper part of a large arch. The cave mouth resembles a crown with bands which have moved upward on both sides (Ferrier, 1995, 74).

The coronation ceremony of Ardeshir in Firuzabad: in this scene depicting the assignment of Ardeshir to the kingship position by the divinity, the king is standing in the presence of Urmazd. The divinity is giving him a crown with ribbons. This crown and the bands attached to it represent Ardeshir (Herzfeld, 2002, 317).

In the rock relief related to Ardeshir and his coronation in Naqsh-I rostam, AhûraMazdâ is the supreme god and even the creation of "Farr" had been attributed to him. Against Ardeshir, AhûraMazdâ who has been appeared as the owner and granter of Farrah due to his numerous achievements is standing. The long and wavy tails have been obviously depicted to visualize the wind-blow or air flow which has had traditionally such a function. However, mixing the wind with turban has not been purposeless; instead, it may have been used to suggest a more important Farrah i.e. the divine Farrah; and it must be added that this has been an illustrative symbol in Shapur's victories in Naqsh-I Rostam rock reliefs (Soudavar, 2004, 38-39).

Ackerman in explaining about the Sassanian band or ascot states that: in a netted figure organized by symbols of rood, 
moon, cock and a figure of a large jeweled palm leaf, which is a representation of a celestial tree, have been placed in a plain loop; or beside it, a ram is taking step as a king, while bands of honor are raised of its jeweled neck, without being clear if it is an Aries or the ancient animal of the moon. Here, the importance of the Sassanian ascot, namely, the raising bands hung over the corners of the royal crown and are considered as the special kingship badges, is clarified. Specialty of these ascots are actualized in different types of the Sassanian king's rock reliefs, even when the large carvings and embellishments were applied in architecture, or they were attached to the symbolic rings of crown reception and power assignment (Ackerman, 2008, 1081).

In Taq-I Bostan, the angles have a turban hung form a carbuncled ring, whereas, in many other scenes, including the figure of Shapur in Bishabur, Fars province, they have only a turban. The later is not for declaring Shapur's reign, but is intended to memorialize his victories over three Roman emperors. Hence, neither a divinity nor an approval ring is seen in this scene. Instead, at the center of this scene, an angle is observed who is bringing him a long turban which resembles a wind-blown headband that Shapur had as if it has been another gift for his victories. The divine Farrah is variant and differentsince splendor can be increased through victory, or may decrease due to defeats, or it might totally be lost, as Jamshid lost his splendor (Soudavar, 2004, 14-17) (Fig. 11).

The significant presence of the ribbons in the Sassanina rock reliefs indicates the importance of this badge. Most of the researchers have a general consensus on the fact that the wavy band or the ribbon is a special indication of the divine Farrah; and they considered it as a gift or present fromAhûraMazdâto the selected person (the Sassanian king). Ribbons have been depicted with various themes in different scenes; for example, in the crown reception of the king from AhûraMazdâ, some ribbons have been attached to the king's clothes and the divinity's clothes, a ribbon has been also hung from the kingship diadem. Also, in the pitched battle scene, it is hung from the king's hat. In the victory scene of Shapur I over the Roman emperors, this ribbon has been brought by an angle to the king. With respect to the fact that ribbon has been regarded as a sign of divine Farrah (splendor), and this Farrah (splendor) is granted by God to the king, as well as being an indication of the divine approval, it has been always along with the king during the battles and various events and it has been never separated from the king.

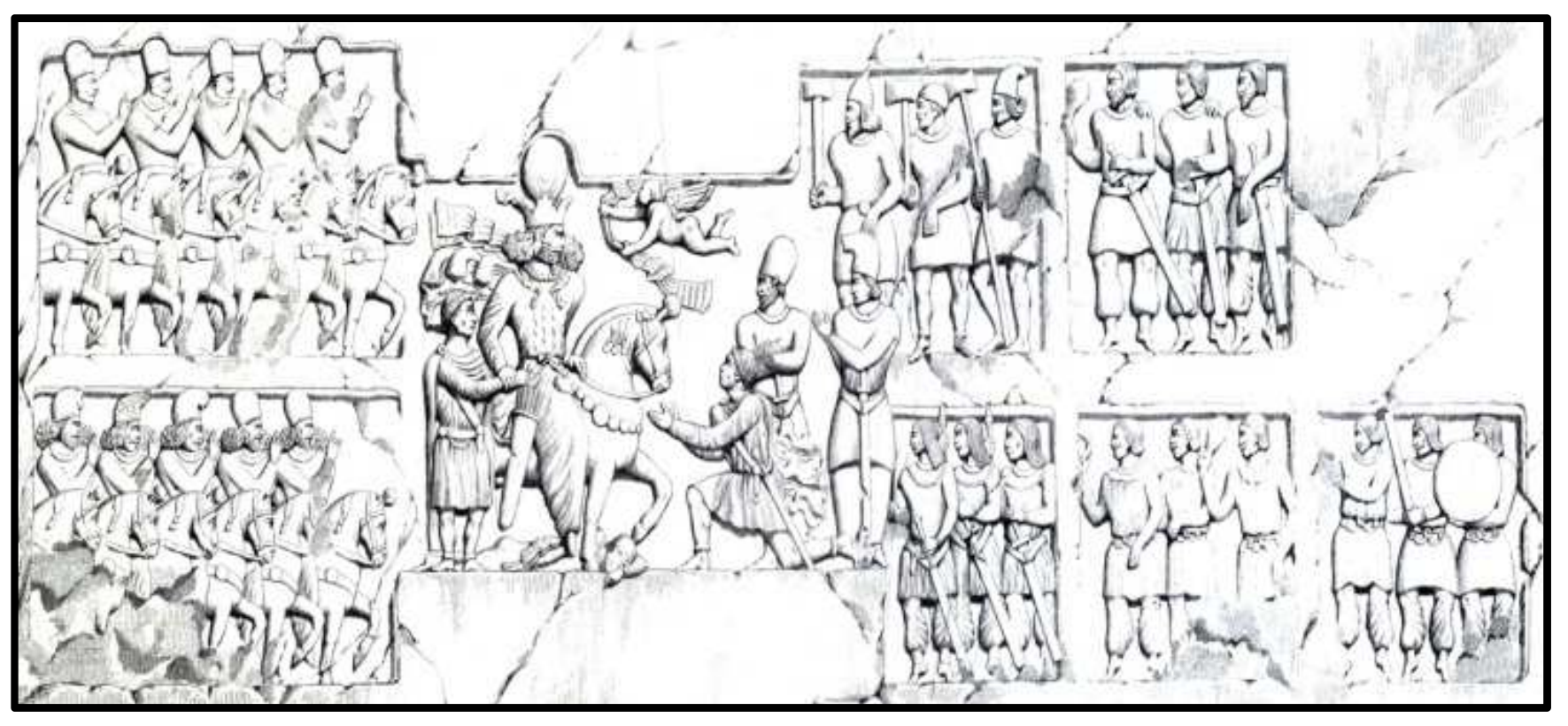

Fig. 11. Bishabur, The victory scene of Shapur I over the Roman Emperors and bringing of the ribbon by the angle to the king (Flandin and Cost,1851-1854: p.49).

\subsection{The Holy Aura Around the Head}

The holy aura is among the special religious badges for granting divinity to the person selected by AhûraMazdâ. This badge can be observed in two rock reliefs related to the hunting scene of Piruz I in the large arch and the coronation assembly of Ardeshir II in Taq-I Bostan (Fig. 5 and 12).

In the Near East, a divinity feature was attributed to a king and his character and the figure was surrounded by a mythical aura (Hinnells, 1994, 70).

In Avesta and Pahlavi texts, the Giti (world) symbol mentioned for Farrah (splendor) is a bird belonging to falcon and hawk family which is very quick moving and flying. When Jamshid's Farrah (splendor) escaped it appeared as a bird. In the coins obtained of the Kushan kings, the previously mentioned light aura is observed around the kings' heads which is an indication of kingship Farrah (splendor) (Amuzegar, 2007, 356 and 357).

As it was mentioned above, the ancient human in order to understand the religious, mythical and metaphysical concepts and notions, engaged in creating material badges for better perception of the spiritual concepts which are beyond their mental limits. Farrah has not been also an exception in this regard and it was visualized in various conceivable forms and 
material elements. Among the most important and well-known types of these forms fire and light can be mentioned since Farrah was appeared in the form of light when it emerged for the first time; and this is the light which is a part of the supernatural origin being or AhûraMazdâ; hence, visualization of this force in the form of light in the Sassanian art has been manifested as a shining aura around the divinities and kings' heads (Movahedi, 2002, 123).

Most often, the material and spiritual appearance of Farrah is imagined as a light in human's mind. In Zoroaster's life story outset, his Farrah (splendor) is in the form of light and brightness. Mehr divinity is visualized with anaura of light which is viewed as an indication of Farrah. In the record book belonging to Ardeshir, the Unifier, it has been stated that: Babak, sees Sassan who has a Zoroastrian and Kiani Farrah in his dream with a light shining from his head (Amuzegar, 2007, $355)$.

In the Iranian mythologies, sphere and semi-sphere are both two symbols of Mitra and they have a broad contribution in symbolization. These have been designed and made as
Mandalay circles. The aura around the head of Jesus and saints and religious paintings are of Mandalay type. Mandalay is the symbol of world for the Buddhists and Hindus which is the world's representative in its relationships with divine forces. In Sanskrit, Mandalay means circle (Afrough, 2010, 28). If we want to consider a definition for the holy aura, it might be interpreted as follows: the divine manifestation and existence in person's faces cause their sanctity and luminous appearance and one would only achieve this through faith and profound belief and faith, piety and knowledge; and the person would internally achieve a particular illumination and enlightenment which all have been obtained through much efforts, and this inner illumination would appear in his face (Elahi, 2005, 58).

The holy aura depicted around the king's head is in indeed an attempt to sanctify his appearance and reign. In fact, the Sassanian kings in order to be able to justify their government used various special kinds of religious badges to attribute themselves to the Zoroastrian spiritual and religious world and to demonstrate God's approval of their reign.

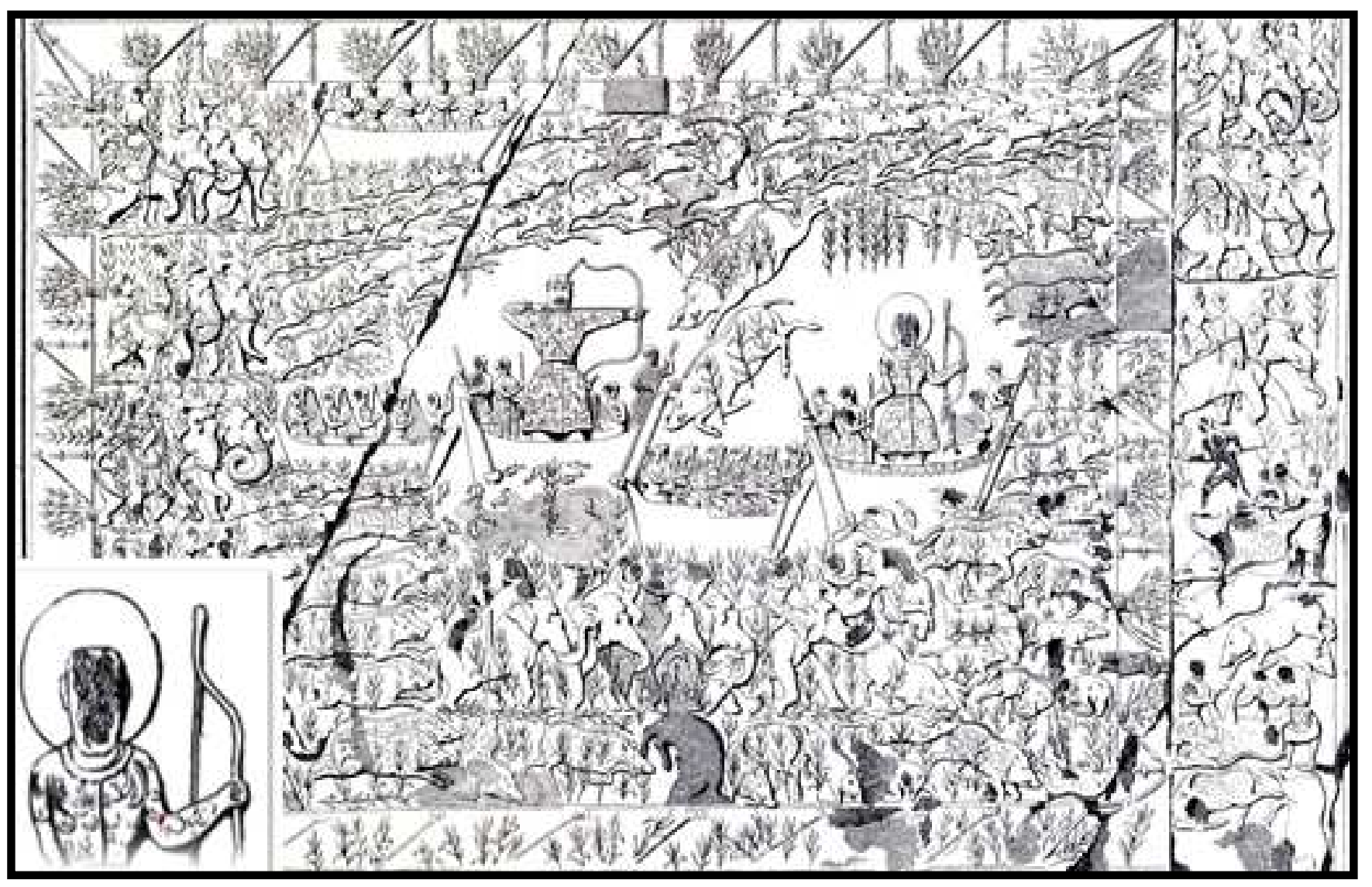

Fig. 12. Taq-I Bostan, the Royal Hunt Scene; the Holy Aura around the King's Head (Flandin and Cost, 1851-1854: p.10).

\section{Conclusion}

Results of the performed studies indicate that most of the symbolic figures and badges in rock reliefs and the emergence of the religious art belong to Ardeshir I period.

The meanings and concepts of the symbolic figures and special badges during the Sassanian period have not undergone any changes and they have retained their original meanings. This suggests that creation of symbolic badges and figures during the Sassanian period has been subjected to a specific and, essentially, stable procedure, and personal tastes have not involved in this procedure. And the symbols and badges used in the rock reliefs throughout the Sassanian period, including coronation ceremony, kingship ring, honor badge, pitched battle, symbol of victory, and other symbols 
which were mentioned above have always had a specific meaning and concept.

The majority of the special badges and symbols applied in the Sassanian rock reliefs are religious symbols and badges which are derived from the dominant religion during the Sassanian age that has had an undeniable effect in creation of the symbol in this period. Among them, some non-religious symbols such as the figures of respect and captivity and pitched battles have been also created in order to express the kings' goals and objectives.

By creating the religious symbols in their artwork, Sassanian sought to legitimize their reign and grant a divine aspect to their state. This was actualized by visualization (incarnation) of the Mazdeandivinities such as AhûraMazdâand Mitra in their figures and rock reliefs. The Sassanian kings intended to suggest this important issue to the spectators that their kingship is a celestial trust dedicated to them by the divinities.

In addition to the presence of the mentioned divinities, special badges such as hearth, holy aura and ribbon, which each one is an indication of Zoroastrianism, were appliedin order to reinforce the divine aspect of the figures and royal assemblies.

Finally, it should be pointed out that the Sassanian art has been a court and royal art, and the artists created the artwork according to the kings and courtiers' demands and requests.

\section{References}

[1] Ackerman, F., (2008): Some Discussions on Early Figure Processing, In the fullness of Iranian art from prehistoric times until today, Translated into Persian by Marzban, P. Vol. II: The Sassanian Period, Supervised by Pope A., and Acreman, F., Edited under Supervision of Parham, S., 1st Edition, Tehran: Elmi \& Farhangi Publications.

[2] Afifi, R., (1995). Iranian Mythologies and Culture in Pahlavi Texts, $1^{\text {st }}$ Edition, Tehran: Tous Press.

[3] Afrough, M., (2010). Symbols and Semiotic in Iranian Carpet, $1^{\text {st }}$ Edition, Tehran: Jamal-e Honar Publications.

[4] Amouzegar, J., (1997). Language (2007), Culture, Mythology, First Edition, PouyayeMoein Publications, Tehran.

[5] Anonymous (1982). Vandidad, translated into Persian by DaeiAleslam, H., M., Second edition, Danesh Publications, Tehran.

[6] Anonymous (1985), Minouy-e Kherad, translated into Persian by Tafazoli, A, second edition, Tous Publications, Tehran.

[7] Anonymous (2003). KhordehAvesta, translated into Persian by Shahmardan R., and Shahmardan, I, second edition, Farvahar Publication Institute, Tehran.

[8] Asil, Sh., (1999). Symbols of the Sassanian Rituals, M.A Thesis in Archaeology, Tehran: Tehran University.

[9] Bahar, M., (2001). Bondheshen Faranbagh Dadegi, 2nd Edition, Tehran: Tous Press.

[10] Black, J., and Green, A., (2004). Encyclopedia of Gods and
Complete Works and Symbols of Ancient Mesopotamia, Translated into Persian by Matin, P. 1st Edition, Tehran: Amirkabir Publications.

[11] Boyce, M., (1997).History of Zoroastrianism, translated into Persian by Sanaatizadeh, H., Vol. I, Second Edition, Tous Publications, Tehran.

[12] Chevalier, J., and Gheerbrant, A., (2006). Dictionary of Symbols, Translated into Persian by Fazayeli, S. Vol. IV. 1st Edition, Tehran: Jeyhoun Press.

[13] Colledge, M., (2004). Parthian, translated into Persian by Rajabnia, M., $2^{\text {nd }}$ edition, Hirmand Press. Tehran.

[14] Cooper, J.C., (2001). An illustrated encyclopaedia of traditional symbols, Translated into Persian by Karbasian, M. $1^{\text {st }}$ Edition, Tehran: Farshad Press.

[15] Christensen, A., (2003). Iran during the Sassanian Periods, Translated into Persian by Yasemi, R. 3rd Edition, Tehran: Sahel and Seday-e Moaaser Publications.

[16] Dixon Kennedy, M., (2006). Encyclopedia of Greco - Roman mythology, Translated into Persian by Behzadi, R. $1^{\text {st }}$ Edition, Tehran: Tahouri Publications.

[17] Elahi, M., (2005). Effects of Holly Aura of the Sassanian Period on Christian Aura, Negareh Periodical, No. 1: pp 57-64.

[18] Farboud, F., Pourjaafar, M., (2007). Investigation of the Iranian Textiles during the Sassanian Period and Eastern Rome (Byzantium), Fine Arts Leaflet, No. 31, pp. 65-76.

[19] Flandin, E and P, Cost (1851- 1854), Voyge en Perse, 2. Vols, Paris.

[20] Frye, R., W., (1995). Iranian Arts, Translated into Persian by Marzban, P. 1st Edition, Tehran, Pajouhesh Forouzan Press.

[21] Guillemin, D., (1996). Ancient Iranian Religion, translated into Persian by Karimi, A., first edition, State Organization of Cultural Heritage Publications, Tehran.

[22] Ghaderi, A., and Khademi, N., (2006). Culture, Investigation of the Effect of the Greek Mythologies Themes on the Sculpture during the Parthian Period, Archaeological Research and Inter-Discipline Studies Periodical. $2^{\text {nd }}$ year, No. 4, pp. 78-90.

[23] Grimal, P., (1968). Dictionnaire de la mythologic Grecque et Romaine, $1^{\text {st }}$ Vol. Translated into Persian by Bahmanmanesh, A. $1^{\text {st }}$ Edition, Tehran: Tehran University.

[24] Ghirshman, R., (1971). Iranian Art (During the Parthian and Sassanian Periods), Translated into Persian by Farah Vashi, B. $1^{\text {st }}$ Edition, Tehran: Publication and Translation Corporation

[25] Ghirshman. (2000). Bishabour, $1^{\text {st }}$ Vol. Translated into Persian by Karimi, A. $1^{\text {st }}$ Edition, Tehran: State Organization of Cultural Heritage Press.

[26] Hall, J., (2001). Illustrated dictionary of symbols in Eastern and Western art, translated into Persian by Behzadi, R., $1^{\text {st }}$ edition, Farhang-e Moaser Publications, Tehran.

[27] Harper, P. O., (2006). Taq-I Bostan and Palatial Traditions in Mesopotamia, Translated into Persian by Kermanjani, Sh., Asar Periodical, No. 40 and 41, pp.140-149

[28] Herzfeld, E., (2002). Iran inthe Ancient East, Translated into Persian by Sanaatizadeh, H. $1^{\text {st }}$ Edition, Tehran: Research Centre of Humanities and Cultural Studies and ShahidBeheshti University of Kerman. 
[29] Hinnells (1994). Recognition of the Iranian Mythologies, translated into Persian by Amouzegar, J., and Tafazoli, A., $3^{\text {rd }}$ edition, Cheshmeh Publications, Tehran.

[30] Hinz, W., (2006). New Findings of the Ancient Iran, Translated into Persian by Rajabi, P. $1^{\text {st }}$ Edition, Tehran: Ghoghnous Press. Tehran

[31] Curzon, S., A., (2003). Iran during the Sassanian Period, translated into Persian by Yasemi, R., $3^{\text {rd }}$ edition, Sahel and Seday-e Moaser Publications, Tehran.

[32] Lukonin, V., (2010). Iran 2. Translated by Masoud Golzari and Mehrdokht Vazirpour Keshmiri, $1^{\text {st }}$ Edition, Tehran.

[33] Malekzade B., B., (1972), Falcon the symbol of Divine Farr, Journal of Historical Investigations, No. 38, $7^{\text {th }}$ year, pp. 11-46.

[34] Mohebi, H., (2011). Conquest, Victory, and Manifestation in Rock Reliefs, Ketab-e Mah-e Honar, No. 12: pp 21-151

[35] Mousavi Haji, S. R., (1995), A Research on the Sassanian Rock Reliefs, M.A. Thesis in Archaeology, TarbiatModares University, Tehran.

[36] Movahedi, S., (2002). Farrah and Its Symbol in the Sassanian Art, M.A thesis, Tehran, Islamic Azad University, Tehran Branch.

[37] Oshideri, J., (1999). mazdean, $2^{\text {nd }}$ Edition, Tehran, Markaz Publications.

[38] Pordada, I., (1979). Art of the Ancient Iran (Pre-historic Civilizations), Translated into Persian by Majidzade, Y., $1^{\text {st }}$ Edition, Tehran: Tehran University Press.

[39] Pourdavoud, E., (1978). Yasnâ, Second Part (A Section of Avesta's Divine Letter), Compiled by Farahvashi, F. $2^{\text {nd }}$ Edition, Tehran: Tehran University Press.
[40] Pourhaghani, M. (2536), Winged Soul, First edition, Zarih Art and Cultural Institute, Tehran.

[41] Rezaeinia, A., (2007). The Artistic Evolution Trend of the Iranian Rock Reliefs, Golestan-e Honar, No. 4, third year, pp. 87-104

[42] Rezaeinia, (2008). Reflection of Iranian Art, Politics, and Religion on Rock Reliefs of the Parthian and Sassanian Periods, National Studies Periodical, 9th Year, No. 4: pp 21-44.

[43] Sarre, Fredrick (2008). The Art of Sassanian Sculpture, A Survey on the Iranian Art since the Pre-historic Times till the Present Day, Persian translation by Marzban, P., second edition: Sassanian Period, Supervisoed by Pope, A., A., and Acremen, F., Edition superviosed by Parham, S., first edition, ElmiFarhangi Press, Tehran.

[44] Shams, A., (2000). A Review on the Symbols and Badges in the Ancient Iran, Visual Arts, No. 8, pp. 194-209.

[45] Smith, J., (2005). Dictionary of Greek and Rome Mythologies, Translated into Persian by Baradaran Khosroushahi, Sh., $1^{\text {st }}$ Edition, Tehran: Rouzbehan and Farhang-e Moaser Publications.

[46] Soudavar, A., (2004-2005). Divine Farrah in the Ancient Iranian Kingship Rituals, first edition, Thompson Publications, Huston, U.S.A.

[47] Ulansey, D., (2001). A New Research on Mithraism, First Edition, Cheshmeh Press. Tehran.

[48] http://oi.uchicago.edu (2014/11/22)Oriental StudiesInstitute of Chicago University. 